\title{
The Case for Employee Board Level Representation in Ethiopian Corporate Governance System
}

\author{
Abdata Abebe Sefara \\ LLB (HU), LLM in Maritime Law (UiO), LLM in International Business Law (CEU), Assistant Professor of \\ Law, Ambo University School of Law, POB 47 (Main Campus Post Office) Ambo, Ethiopia
}

\begin{abstract}
The participation of workers in the management of companies brings benefits. Many European jurisdictions have recognized workers' involvement in the management of firms in diverse forms and to varying degrees. The board level representation is believed to be the strongest of all the mechanisms. In some jurisdictions the laws require a full and legally mandated representation of employees in supervisory boards of the largest firms. Several other countries also have corporate laws that allow the representation of workers in a board room. As a result, a recent discourse in corporate governance deals with a multi stakeholders including the labour. However, the mainstream corporate governance discourse in Ethiopia is restricted to discussions mainly from the perspective of shareholders. By disregarding employees as stakeholders in corporate governance of their firms, Ethiopian laws stand in a sharp contrast to the approach of corporate governance that allows a board level representation of firms' workers. This article shall, by examining experiences of some European jurisdictions and analyzing the relevant Ethiopian legislations, questions whether Ethiopia's prohibition of board level employee representation in corporate governance of share companies is justified. It also inquires whether the European style of employee board level participation is feasible in Ethiopia or an alternative (practical) style of employees' board level participation should be crafted.
\end{abstract}

Keywords: Corporate governance, board structure, employee representation, Ethiopia

DOI: $10.7176 / \mathrm{JLPG} / 84-02$

Publication date: April $30^{\text {th }} 2019$

\section{Introduction}

Employee participation (also called worker participation, employee involvement, industrial democracy or employee voice) is a disputed concept. In the first place, there is no universally acceptable definition of employee representation across corporate laws of countries. Yet, literatures describe employee participation as a concept generally referring to decision rights and actual involvement by workers in the management of their firm. From European perspective, employee participation might include 'statutory and collective agreement provisions for employee participation through works councils and similar bodies and forms of board-level representation, in addition to provisions for systematic consultation and information disclosure. Secondly, whether certain jurisdiction recognizes workers' participation depends on the style of corporate governance it adopts. Board Level employee representation of practiced mostly in countries which adopt a dual corporate boards where as countries with monolithic boards very often practice other forms of employee representation in corporate governance instead of a board level representation.

The practice of employee representation in fact depends on the question what approach of corporate governance is adopted in that country. Based on whose interests are protected and who should actually take part in the management of firms there are generally two competing approaches to corporate governance. The first (and a rather dominant ideology) to corporate governance is called shareholder value model. ${ }^{1}$ As per this view, the primary objective of companies is to maximize the ownership interests of shareholders. This contrasts with the stakeholder perspective, in which an equally legitimate objective is to serve the interests of employees and other stakeholders. ${ }^{2}$ The shareholder value model is adopted mostly in Anglo-American systems. A brief perusal of Ethiopian company laws, which traces its origin to continental Europe than Anglo-American, reveals that the shareholder value model is recognized. ${ }^{3}$ In other words companies are required to operate only in the interests of the shareholders, as the owners of the company. Here it is worth mentioning that Ethiopia does not have a corporate governance code and a national stock market. A limited journal articles published in different law journals and a quick perusal of the relevant legislations proves that a corporate governance discourse in Ethiopia limits itself to the regulation of the relationships between agents (managers) and principals (shareholders). The relevant chapters

\footnotetext{
${ }^{1}$ Shareholder value in this context means the value delivered to shareholders because of management's ability to grow sales, earnings and free cash flow over time.

${ }^{2}$ Robert H Kleinknecht, Employee Participation in Corporate Governance: Implications for Company Resilience, European Journal of Industrial Relations, Vol. 21, No.2015, p-58.

${ }^{3}$ One may wonder why the then European professors who drafted the Ethiopian Commercial Code preferred the shareholder value model. Perhaps they were either of an attitude that a business environment in Ethiopia at that time was not ready to accommodate the stakeholder model.
} 
of the Commercial Code of the 1960, for instance, emphasize only on shareholders meetings, directors, managers and auditors to the exclusion of employees. The Code requires share companies to be managed only by its shareholders-a typical principle in jurisdictions upholding the shareholders' supremacy. A normative trend in Ethiopia appears to exclude the protection of interests and rights of employees out of the ambit of corporate laws.

The alternative and broader approach to governance of firms is called the stakeholder model. This model considers companies as 'social organization dependent upon the contribution of different groups to the production of goods and services'. ${ }^{1}$ Consequently, it recognizes the participation of multiple stakeholders such as workers, suppliers, managers, creditors, customers and government alongside shareholders. ${ }^{2}$ Corporate governance models in continental Europe and Japan give greater weight to employee interests. ${ }^{3}$ Contrastingly, the American corporate governance style is characterized by the separation of ownership and control, diversified shareholders with strong legal protections and there is a presumption that management should maximize shareholder value. ${ }^{4}$ Hence, the primary focus of the corporate governance debate in the US has been the creation of wealth. A brief summary of the comparison between the two systems is provided in the following table. ${ }^{5}$

\begin{tabular}{|l|l|l|}
\hline Basis of Comparison & Anglo-American & Continental European and Japan \\
\hline Law & Common law & Civil law \\
\hline Market organization & Liberal & Coordinated \\
\hline Labour market turnover & High & Low \\
\hline Acquisition of labour skills & External & Internal \\
\hline Collective bargaining & Decentralized, company level & Centralized, Sector level \\
\hline Internal worker representation & Non-existent & Existent \\
\hline
\end{tabular}

Even though there is no such a thing as one size fits all and the corporate governance paradigm of different jurisdictions depends among other things on the prevalent economic policy adopted in that jurisdiction, different studies show that considering interests of workers in a corporation broadens the stakeholders, enables companies to discharge their public role in through shaping the lives of workers and the society at large. ${ }^{6}$ It also believed to play a crucial role in creating sustainable companies that function properly. Hence, as the success of a company depends on the knowledge, skills and commitment of employees, corporate governance should be reframed in such a way to motivate them. In line with this position, I argue that the position adopted under Ethiopian laws that fully prohibits workers from taking part in a governance of their firms is misguided and needs to be reconsidered.

\section{Employee Participation in Corporate Governance: A Foreign Experience}

Before moving on to the analysis of relevant Ethiopian laws in relation to corporate governance it is important to look at the modes of employee representation in firms in general and the experiences of some foreign jurisdictions. Different mechanisms are utilized to ensure workers participation in corporate governance. Notably: employees may be entitled to have access to information ${ }^{7}$, be consulted on certain corporate decisions or even take part in corporate decisions via their permanent representatives in boards (co-determination). Companies can also enhance employees' commitment and firms' productivity through employees' equity ownership scheme. Besides, collective bargaining through trade unions, works council, worker 'consultative' representative in boardrooms, worker involvement in selection of top management team and worker representation at the annual general meeting are also forum of advancing workers interests in firms.

\subsection{Board Level Representation (BLR)}

From the discussion above we have realized that there are diversified platforms to make the voices of workers heard in the management of firms. Amongst those platforms, a more powerful form of participation of employees is via workers' membership to executive or supervisory boards. BLR differs from employees' access to information and consultation on the daily operation of firms in the way that the former provides workers' input

\footnotetext{
${ }^{1}$ Kleinknecht, supra note 2, p-15.

${ }^{2}$ The stakeholder approach to corporate governance of firms is gaining a wider acceptance in a contemporary discourse of corporate governance and it will be the focus of this paper.

${ }^{3}$ Sanford M. Jacoby, Employee Representation and Corporate Governance: A Missing Link, University of Pennsylvania Journal of Labor and Employment Law, Vol. 3, Issue 3, p-450.

${ }^{4}$ Edward J. Epstein, Who Owns the Corporation? Management vs. shareholders, Priority Press Publications, 1986.

${ }^{5}$ Source: Howard Gospel and Andrew Pendleton, Corporate Governance and Labour Management: An International Comparison, Oxford University Press, 2005, ISBN 0199263671

${ }^{6}$ Brett H. McDonnell, Strategies for an Employee Role in Corporate Governance, Wake Forest Law Review, Vol-46, Issue-1, 2011, p-429. Also See Irene Lynch, Working Within Two Kinds of Capitalism_Corporate Governance and Employee Stakeholding: US and EC Perspectives, Hart Publishing, 2003, Oxford, p-7

${ }^{7}$ The possession of information by employees and their representatives may range from information on tasks, on performance or on broader strategic plans. Information sharing is thus not a type of employee representation as such but is integral to all forms.
} 
into the corporate strategic decision-making. ${ }^{1}$ It is possible through employee or trade union delegates who sit in corporate boards. BLR is designed to foster communication and decision making between the board, the CEO and employees and provide opportunity to workers to discuss alternative corporate strategies that secure socially tolerable results within the objective of financial sustainability. ${ }^{2}$

The board level participation of workers varies from jurisdiction to jurisdiction. They vary in the manners of elections, legibility, which companies are required to have workers in their boards, number of worker representatives, and the board structure. ${ }^{3} \quad$ Fourteen of the 28 EU Member States plus Norway (i.e. 14 out of 29) have significant rights for workers to be represented on company boards. These countries are Austria, Croatia, the Czech Republic, Germany, Denmark, Finland, France, Hungary, Luxembourg, the Netherlands, Norway, Sweden, Slovenia and Slovakia. Austrian companies have supervisory boards which oversee the action of the executive board, which runs the business on a day-to-day basis. The works council has the right to choose one-third of the representatives of the supervisory board in companies with at least 40 employees. ${ }^{4}$

In the dual board system of Netherlands, companies with more than 100 employees, a works council and a set amount of capital must set up a supervisory board. The supervisory board elects its own members and the shareholders, the works council and the executive board have the right to recommend new members. There is no fixed proportion of employee representatives on the board: a works council may uses its right of recommendation, but employees do not necessarily have a real representative on the board. According to the Civil Code, members of the supervisory board must take the interest of the company and the undertaking as a whole into account in the fulfillment of their duties; they are not employee representatives as such. ${ }^{5}$

Board-level representation is widespread in Sweden. In almost all companies with more than 25 employees, employees have the right to two board members. In companies with more than 1,000 employees engaged in at least two types of businesses, this rises to three board members. The employee representatives can never be in a majority. ${ }^{6}$

Besides, Greece, Ireland, Poland, Portugal and Spain have more limited rights to board representation, mainly in state-owned or privatized companies. ${ }^{7}$ This means that in 19 out of 28 EU member States plus Norway (i.e., 19 out of 29) have some provision for workers' representation on company boards. ${ }^{8}$ Yet compared to Germany employee representatives constitute a minority of board members. The section below briefly elaborates on the twotier board structure in German Stock Corporations and the participation of employees at the level of supervisory board.

\subsubsection{Supervisory Codetermination in Germany}

In the discussion above we have concluded that in many European countries the concept of employee representation in corporate boards has been recognized. Despite the recognition of BLR in several countries literatures on the subject matter reveals that the position adopted in Germany has attracted attention of many writers and resulted in a massive body of publications. This fact is attributed to a somehow unique approach adopted under the German laws. ${ }^{9}$ The discussion below seeks to briefly introduce this peculiar German approach to BLR.

The board of directors of German stock corporations are composed of mandatory two-tier separate wings, the supervisory board and the management board. ${ }^{10}$ The labour is represented in the supervisory boards. This practice of accommodating representatives from labour has been in place for long time in Germany. Despite recent challenges against effectiveness of the supervisory boards of German stock corporations ${ }^{11}$ and the possible adjustments due to developments at European Union level, the German style of labor participation has always remained unique. German corporate laws allocate employee representatives half of the seats on a company's

\footnotetext{
${ }^{1}$ Roy Jones and Pierre Habbard, Workers'Voice in Corporate Governance - A Trade Union Perspective, Global Unions Discussion Paper, September 2005, p-20, available at, Accessed on 02/12/2016

${ }^{3}$ Janet Williamson , Workers on Board: The Case For Workers' Voice In Corporate Governance, Economic Report Series 2013, p-20, https://www.tuc.org.uk/sites/default/files/Workers on board.pdf (last time accessed on November 25, 2016)

${ }^{4}$ European Industrial Relations Observatory and Worker representation in Europe, Labour Research Department, LRD Booklets, March 1998.

${ }^{5}$ Ibid.

${ }^{6}$ Ibid.

${ }^{7}$ Williamson, supra note 13 , p-20.

${ }^{8}$ ibid.

${ }^{9}$ Germany is chosen as a European jurisdiction that mandates maximum rights of employees' involvement in corporate boards.

${ }^{10}$ Regarding the allocation of powers between the two-tier boards, a management board is in charge of the day-to-day functions of a corporation whereas a supervisory board as apparent from its designation supervises and advises the management board, appoint and revoke the management board, follows up the management board's compliance with the company statutes, the law and its business objectives. ${ }^{10}$ It is also responsible for bringing the actions of the company against members of the management board.$^{10}$ In principle, the management board is independent from the shareholders and the supervisory board in its regular functions. Nonetheless, actions of the board should protect 'the best interest of the corporation'. ${ }^{10}$

${ }^{11}$ The recent corporate scandals of Mannesmann AG (2000) and Volkswagen (VW) AG (2006) have casted shadow over the efficacy of employees' representations in the supervisory boards. The labour representatives in the supervisory boards of these companies have neglected interests of the labour and finally drove their respective companies into crisis. Consequently, studies have been underway to propose modifications to the existing supervisory codetermination.
} 
supervisory boards of stock corporations. The supervisory codetermination-representation at the board level enables the employee representatives to participate in the supervisory board of their company. ${ }^{1}$ The powerful constituencies often represented in the supervisory board are employees' representatives', banks and block holders. ${ }^{2}$ It rests on the view that equity capital suppliers and the providers of labor run the firm cooperatively'. ${ }^{3}$ Germany has recognized codetermination since $1920 \mathrm{~s} .{ }^{4}$ Currently, the composition and overall aspects of the supervisory co-determination in Germany is governed by different legislations depending on the nature of a corporation. Accordingly, the Codetermination Act of the 1976 governs the composition of supervisory board of corporations other than the coal, iron and steel corporations which has a separate Codetermination Act of $1951 .{ }^{5}$ In accordance with the 1967 Codetermination Act, a stock corporation (AG) with more than 2000 workers is obliged to have employee representatives in the board of supervisors. ${ }^{6}$ The notion of codetermination evidences that corporate managers in Germany are committed to protecting interests of the diverse stakeholders. ${ }^{7}$ Despite the popularity of co-determination in Germany, there are criticisms and pleas for policy and legislative changes. ${ }^{8}$ Yet the German corporate governance model has always been in strong favor of representing labor in the corporate boards.

\section{The Ethiopian Law and Employee Representation on Corporate Boards \\ 3.1. General Background}

Corporate governance is a relatively new subject matter in Ethiopia. The term 'corporate governance', is rarely used in law school curricula, in practice as well as in legislations. There are no enough literatures on the subject matter of corporate governance in Ethiopia. Even the existing scanty works have denied attention to participation of labor in the management of companies. There is a consensus amongst practitioners and academics that the existing legal regimes do not provide a sufficient legislative response to the modern intricate questions of company laws and corporate governance. This is believed to be some of the many reasons that prompted an on-going revision of the 1960 Commercial Code. ${ }^{9}$

The Commercial Code recognizes private limited companies and share companies as two forms of companies. As forming and managing private limited companies is relatively easy, there are large numbers of private limited companies compared to share companies in Ethiopia. The emergence of share companies through public subscription of shares is relatively a recent development. Yet they have the potential of creating jobs and making a significant contribution to the country's economic development. The discussion here is limited to (public) share companies, i.e. companies formed through sale of shares to the public.

\subsection{Prohibition of Employees' Involvement in Ethiopia's Monistic Board System}

The Ethiopian Commercial Code recognizes shareholders meetings, the board of directors and auditors as organs of management. ${ }^{10}$ Although shareholders participate in important corporate decisions through shareholders meetings, the highest power of share companies vests with the board of directors. In contrast to the two tier board models adopted in some continental European jurisdictions, the Commercial Code has adopted a 'single tier' (unitary) board model.

In principle, corporate boards might be composed of shareholders as well as non-shareholders. The question whether persons other than shareholders qualify to become directors or not has different answers depending upon

\footnotetext{
${ }^{1}$ Fukuyama Fransis,Trust: The Social Virtues and The creation of Prosperity, Free Press, 1995, p-217.

${ }^{2}$ ibid, p-65.

${ }^{3}$ Gary Gorton and Frank A. Schmid, Capital, Labor and the Firm: a Study of German Codetermination, Journal of European Economic Association, Vol-2, No-5, 2004, p-84

4 Rebecca Page, Co-Determination in Germany: a Beginners' Guide, Hans Bokler Stiftung, Arbeitspapier33, 2009 , p- 5. http://www.boeckler.de/pdf/p arbp 033.pdf last time accessed on July 22, 2016

${ }^{5}$ This act calls for the one-third membership of workers representatives in the supervisory board of the coal, iron and steel corporations.

${ }^{6} \S 7(1)$ of the Co-determination Act, 1976. The numbers, composition and manners of appointment of the employee representatives are governed by this Act. In an AG with less than 10,000 the supervisory board should be composed of six employee representatives and six shareholders representatives. For AGs with 10,000 up to 20,000 employees, the board of supervisors is composed of eight members from the employee's representative and eight from the shareholders representatives. If AG employees more than 20,000 workers the law requires ten representatives of shareholder and ten representatives of workers. ${ }^{6}$ The employees' representatives themselves are composed of the current workers of the company and 'trade union representatives'.

${ }^{7}$ In spite of the AG managers' commitment to satisfy the interests of diverse stakeholders, there are mechanisms under German laws to ensure that the considerable weight is given to shareholders interests. For instance, shareholders control the tie-breaking vote.

${ }^{8}$ Critics, among other things, forward: the board of supervisors increased focus on the labor matters instead of supervising the management board, the increasing number of membership hampers the smooth decision making in the board of supervisors, the exclusion of the companies workers abroad, and the possible conflict of interests. ${ }^{8}$ These potential problems coupled with the legal developments at the European Union level may bring changes to the legal rules regarding the supervisory codetermination of workers in Germany in the future. See also: Jean du Plessis and Ingo Saenger, The German System of Supervisory Codetermination by Employees, inDuPlessis et al., German Corporate Governance in International and European Context, Springer, 2007, p-125-127.

${ }^{9}$ The progress of the works of revision on this date of writing this article is unknown and the old Commercial Code is still in force

${ }^{10}$ Arts-347-428 of the Commercial Code
} 
a jurisdiction concerned. The response is positive means there is a likelihood for representation of non-shareholders including employees in corporate boards. It is impossible to have (non-shareholder) employee as board members in jurisdictions that deny inclusion of non-shareholders in corporate boards. The norm in many continental and Anglo-American systems mandates or at least recommends inclusion of the non-shareholders and/ independent member/sin corporate boards.

In Ethiopia, only shareholders qualify for the directorial position of a share company as per Art-347 of the Commercial Code. This formula is built on a questionable assumption that directors would be more diligent in carrying out their duties when they have ownership interests in their company. The precondition of being a shareholder is further strengthened by the rules that require directors to deposit their registered shares-the numbers of which is decided in the memorandum of association- as a security with their company. ${ }^{1}$

Now let us see the implication of rules that restrict board membership only to shareholders. The rules limit membership to the board of directors only to physical persons or corporate entities that own a company's shares squarely avoid the possibility of including independent /external members and employees inboards of share companies. In the first place, these stakeholders are not shareholders hence do not satisfy the requirement of being shareholders. Moreover, non-shareholder employees cannot deposit the so-called 'qualification shares' under art349 with the company. ${ }^{2}$

One may wonder how European professors who drafted the Commercial Code of 1960 have ignored a possibility of appointing non-shareholder as a director. There is no doubt that they were more familiar with the continental European stakeholder model of corporate governance than the Anglo-American shareholder value model. Yet either for the sake of simplicity or some other reasons, the drafters opted for the shareholder value model that advocates shareholders' supremacy. ${ }^{3}$ Thus, it does not come as a surprise that the existing legal regime avoids the representation of labor in the corporate governance. ${ }^{4}$ The same goes for the involvement of outsider/independent directors. Even the legal systems known for being a typical shareholder value model, such as the state of Delaware in the US recognize independent board members. However, the Ethiopian laws do not oblige share companies to have independent director/s in their board.

The matter of employee representation in the board of directors has not been relevant to company laws in Ethiopia. Nowhere in the Ethiopian Commercial Code, has the law mentioned about a platform for employees participation in corporate governance. The normative trend in Ethiopia appears to leave the protection of labour out of the scope of corporate laws expectedly to the fields of contract laws and labor laws. As pointed out above, membership to boards of directors in Ethiopian share companies is reserved for shareholders only. ${ }^{5}$ It impliedly prohibits firm employees from being members of the board of directors. A shareholder employee perhaps is not disqualified to seat in the board of directors. However, it does not mean employees are represented in the board of directors. The laws governing financial share companies such as banks are straightforward compared to an implied prohibition made under the Commercial Code. ${ }^{6}$ Bank employees, ${ }^{7}$ be temporary or permanent are prohibited from membership to a board of directors of their employer bank as well as any other bank.

In practice, the daily operation of a share company is run by a general manager (CEO) who may not necessarily be a shareholder. One may inquire how employee representation is considered denied when a share company is actually run by personnel who could possibly be an employee himself. Compared to the CEO's powers, the position of board of directors is more of 'ceremonial' with powers limited to defining the policies of company and approval of strategic corporate decisions. The problem however is, the law does not make a clear demarcation of powers between the board of directors and 'the executives who make momentous decisions'. ${ }^{8}$ As per Art- 348 (1) of the Commercial Code, the general manager is appointed and removed by board of directors. By doing so, the board will retain its power over the general manager. An employee (non-shareholder) general manager does not represent workers of a company, as employees have no say in his appointment and removal. It then has no

\footnotetext{
${ }^{1}$ Art. 349. - Qualification shares.

1. The directors shall deposit as security with the company such number of their registered shares in the company as is fixed in the memorandum of association.

2. These shares shall not be handed back until the owners have ceased to be directors and have fully discharged their liabilities, if any, to the company.

${ }^{2}$ The traditional principle of company law; 'the supremacy of the shareholders' has earned its utmost manifestation in this specific provision ${ }^{3}$ The model has remained unchallenged as all relevant legislations enacted after the commercial Code has also uncontested it.

${ }^{4}$ As there are no supervisory boards akin to the Germany system, the boards of directors of Ethiopian share companies are the only possible forum to accommodate workers representation in the highest level of management. Also see: Hussein Ahmed Tura, Reforming Corporate Governance in Ethiopia: Appraisal of Competing Approaches, Oromia Law Journal, Vol-3, No-1, 2014, p-184.

${ }^{5}$ Art-347 Com. C.

${ }^{6}$ Art-5 of 'Limits on Board Remuneration and Number of Employees who sit on a Bank Board Directives No.SBB/49/2011. Art-2(5) of the same Directive states 'bank employee' includes the chief executive officer and any other worker of a bank involved in the daily business activities of a bank.

${ }^{7}$ Art-2(5) of the same Directive states 'bank employee' includes the chief executive officer and any other worker of a bank involved in the daily business activities of a bank.

${ }^{8}$ Tewedros Meheret, Governance of Share Companies in Ethiopia, Ethiopian Business Law Review, Vol- IV, 2011, p-79.
} 
relevance for representation of employees in corporate decision-making.

\subsection{The Case for Opening the Boardroom to Employees: Why and How?}

The fundamental reason for workers' voice in corporate governance is that workers' interests are affected by the priorities and decisions of company boards and it is a fundamental matter of justice that they should be represented within those discussions. ${ }^{1}$ It also invokes a question whether there is a correlation between workers participation in corporate governance and firms' performance on one hand and a relationship between corporate governance and labor practices on the other hand. Although it is hard to calibrate with accuracy, there is a connection between a corporate governance system and labor practices. ${ }^{2}$ The fact that 'every continental European countries has legally mandated works councils, and that some European countries even have mandatory health and safety councils and employee representation on corporate boards, provide evidence of this'. ${ }^{3}$ Besides, studies show that countries with strong workers' participation rights perform better on a wide range of factors than those with weak workers' participation rights. The table on the European Participation Index (2008-2009) below evidences this finding. ${ }^{4}$

\begin{tabular}{|l|l|l|}
\hline Europe 2020 Headline Indicator & \multicolumn{1}{|c|}{$\begin{array}{c}\text { Group I } \\
\text { Countries with stronger } \\
\text { participation rights }\end{array}$} & $\begin{array}{l}\text { Group II } \\
\text { Countries with } \\
\text { participation rights }\end{array}$ \\
\hline $\begin{array}{l}\text { Employment rate by gender, age group 20-64 } \\
(2009)\end{array}$ & 72.1 & 67.4 \\
\hline $\begin{array}{l}\text { Gross domestic expenditure on R\&D (GERD) } \\
(2008)\end{array}$ & 2.2 & 1.4 \\
\hline $\begin{array}{l}\text { Share of renewables in gross final energy } \\
\text { consumption (2008) }\end{array}$ & 12.3 & 6.1 \\
\hline Energy intensity of the economy (2008) & 171.2 & 181.7 \\
\hline $\begin{array}{l}\text { Early leavers from education } \\
\text { and training (2009) }\end{array}$ & 14.0 & 16.1 \\
\hline $\begin{array}{l}\text { Tertiary educational attainment } \\
\text { by gender, age group 30-34 (2009) }\end{array}$ & 36.6 & 31.1 \\
\hline $\begin{array}{l}\text { Population at risk of poverty or exclusion } \\
\text { (2008) }\end{array}$ & 19.1 & 25.4 \\
\hline
\end{tabular}

Coming back to the Ethiopian case, as pointed out above Ethiopian laws stick to the classical principle of 'the supremacy of the shareholders' in the conduct of affairs of companies. The institution of BLR as a tool of labour representation in corporate governance is entirely unknown. By prohibiting the employees, involvement in the (only) possible forum of representation -the board of directors- without providing an alternative forum, the legal system appears to fully ignore it. Then, the question remains, should Ethiopia preserve its legal regimes that prohibit workers involvement in corporate governance amidst the research findings proving contribution of workers' involvement to company success elsewhere? If no, what would be the possible mechanism to recognize employees' board level participation?

A response to the first question is that there is no reason why employee representation, with its proven contribution to the long term successes of companies, wouldn't be important in Ethiopia. With regard to the second question, one of the possible mechanisms through which workers defend themselves against exploitation by the capital interests is unionization. Trade unions are venues to advance the interests of workers through collective bargaining and the resulting collective agreements. In many countries unions are involved to in the nomination of candidates to employee representatives in corporate boards. As unions go stronger to gain better wages and working conditions they might eventually end up claiming board level participation. This was the case at least in Germany and Scandinavian countries. ${ }^{7}$ The right to make association through trade union is recognized under the Ethiopian labour laws. As a member of International Labor Organization (ILO) Ethiopia has a mandate of implementing the ILO conventions and other regional instruments it has ratified. Art 42 of the FDRE constitution recognizes the trade union rights. Besides, the Labor Proclamation No. 377/2003 details the institutional and legal regimes for the proper implementation of this right. This proclamation requires a minimum number of ten members

\footnotetext{
${ }^{1}$ Williamson, supra note $13, \mathrm{p}-19$.

${ }^{2}$ Jacoby supra note 6, p-458.

${ }^{3}$ id.

${ }^{4}$ Source: Sigurt Vitols, The European Participation Index (EPI): A Tool for Cross-National Quantitative Comparison, European Trade Union Institute, October 2010. (www.worker-participation.eu/About-WP/European-Participation-Index-EPI) last accessed on December $30,2016$.

${ }^{5}$ Group I countries: Austria, Denmark, Finland, France, Germany, Greece, Luxembourg, the Netherlands and Sweden

${ }^{6}$ Group II countries: Belgium, Bulgaria, Cyprus, the Czech Republic, Estonia, Hungary, Ireland, Italy, Lithuania, Latvia, Malta, Poland, Portugal, Romania, Slovakia, Slovenia, Estonia, UK.

7. Gregory Jackson,Employee Representation in the Board Compared: A Fuzzy Sets Analysis of Corporate Governance, Unionism and Political Institutions,IndustrielleBeziehungen, 12. Jg., Heft 3, 200, p-8.
} 
to establish a trade union. ${ }^{1}$ Thus, except for companies prohibited by the labour laws ${ }^{2}$, workers of share companies in Ethiopia have the right to form trade unions.

However, the prospect of claiming BLR without legal regimes allowing trade unions to do so is minimal. It is true that trade unions both under ILO laws and Ethiopian labor laws are meant to take part in collective bargaining-the scope of which is limited to terms and conditions of employment. ${ }^{3}$ The author is of the opinion that the ideal candidates for participation in boards of share companies in Ethiopia are representatives of trade unions and the necessary legislative reforms allowing representation should be considered. It may also be argued that the enterprise level unions might be too isolated and weak to claim BLR. The reality in Ethiopia reveals that workers and labor unions have to go a long way to gain a political power strong enough to claim their share in corporate governance.

The proposition is that countries with strong unions and coordinated collective bargaining are more likely to have board-level representation than countries with weak unions and less coordinated collective bargaining. ${ }^{4}$ The concerns of workers would be better addressed if the relevant laws allow representatives of trade union of share companies to seat in corporate boards. This in a way extends the role of trade unions from merely focusing on the areas of working conditions, safety and health issues to participate in the formation of important company's policies.

The question that necessarily follows is a full-fledged codetermination rights in the social free market economies like in Germany feasible in Ethiopia? What possible model fits to the existing monistic board of directors in Ethiopia? The practice in many jurisdictions reveal that workers have legal rights to board-level representation in private firms in Austria, Denmark, Germany, Norway, Sweden, where as they enjoy legal rights to nominate some members to the board in Finland and Netherlands. Countries with dual board system do not seem to be potential models, as its adoption in Ethiopia requires significant changes to the existing board system. Hence, the possible model could be Sweden. ${ }^{5}$ The concern of workers in Ethiopia can be addressed at the board level without making them a majority, as it is the case in Sweden. In this way, the resistance from the side of shareholders can be minimized. Adopting a style similar to that of Sweden in Ethiopia looks a wise choice. Nevertheless, its implementation requires the necessary legislative changes that among other things determines, who qualifies, what type of companies with what number of workers should install employees' BLR and other similar issues.

\section{Concluding Remarks}

The corporate governance discourse in Ethiopia focuses on shareholders, directors and auditors. It rarely considers employees relevant. Ethiopia should not preserve its company law rules prohibiting employee involvement in the management of firms amidst the research findings indicating merits of the representation. The provisions prohibiting workers from seating in the board of directors are misguided. They evidence Ethiopia's cynicism on the participation of workers in corporate governance. The legally mandated system of employee co-determination akin to the workers codetermination in Germany perhaps does not work in Ethiopia. Yet there should be available rooms for the decision-making powers of workers in share companies. It is highly desirable to have representative/s of labor in the board that can address the concerns of employees. This will in turn increase the workers' motivation, firm's operational efficiency and fight the 'short termism'.

The possible candidates to BLR in Ethiopia are the representatives of trade unions in share companies. However BLR is not allowed as the Ethiopian laws stand today. The initial step towards workers BLR in Ethiopia involves legislative reform to the relevant company laws prohibiting BLR and amendments to labour laws to extend the scope of activities of trade unions to BLR. One can easily rule out the suggestion made here only as a

${ }^{1}$ Art 114(1) of the Labour Proclamation No. 377/2003

${ }^{2}$ Art 136(2) of the Labour Proclamation No. 377/2003 states: "essential public services undertakings" means those services rendered by undertakings to the general public and includes the following:

(a) air transport;

(b) undertakings supplying electric power;

(c) undertakings supplying water and carrying

out city cleaning and sanitation services;

(d) urban bus services;

(e) hospitals, clinics, dispensaries and pharmacies;

(f) fire brigade services; and

(g) telecommunication services

${ }^{3}$ Art-115 of the Labour Proclamation states the functions of trade unions as:

Observe the conditions of work and fulfill the obligations set forth in this proclamation; respect the rights and interests of members in particular, represent members in collective negotiations and labour disputes before the competent body when so requested or delegated.(...).

${ }^{4}$ Jackson, supra note 46 , p-9.

${ }^{5}$ Board-level representation is widespread in Sweden. In almost all companies with more than 25 employees, employees have the right to two board members. In companies with more than 1,000 employees engaged in at least two types of businesses, this rises to three board members. The employee representatives can never be in a majority. (From European Industrial Relations Observatory; and "Worker representation in Europe", Labour Research Department, LRD Booklets, March 1998) 
work of an ambitious academic. But what looks impossible today may be imaginable in the future. As Keynes mentioned:

Practical men, who believe themselves to be quite exempt from any intellectual influences, are usually the slaves of some defunct economist. Madmen in authority, who hear voices in the air, are distilling their frenzy from some academic scribbler of a few years back '...'.

${ }^{1}$ John Maynard Keynes, The General Theory of Employment, Interest, and Money, 1936, p-383 